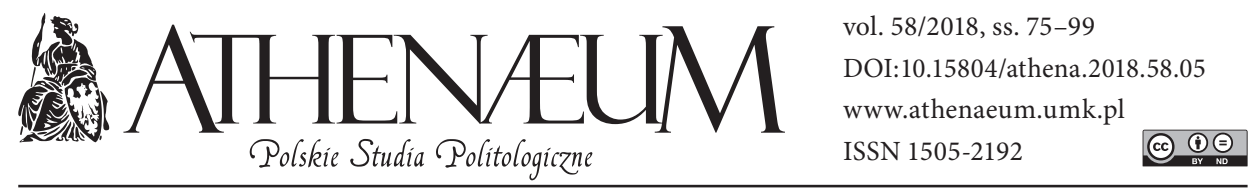

\title{
ZMIANA PRZEPISÓW KODEKSU WYBORCZEGO PRZED WYBORAMI SAMORZĄDOWYMI 2018
}

\author{
CHANGE OF THE ELECTORAL CODE \\ BEFORE LOCAL GOVERNMENT ELECTIONS IN 2018
}

Bartłomiej Michalak*

\begin{abstract}
ABSTRAKT
11 stycznia 2018 r. Sejm RP uchwalił ustawę wprowadzającą wiele zmian do Kodeksu wyborczego. Najważniejsze zmiany dotyczyły administracji wyborczej, komisji wyborczych oraz praw wyborczych. Artykuł analizuje szczegółowe konsekwencje polityczne najważniejszych $\mathrm{z}$ tych reform. Autor dowodzi, że część z tych zmian, w szczególności dotyczących struktury Państwowej Komisji Wyborczej i administracji wyborczej jako takiej, może doprowadzić do kryzysu organizacyjnego i politycznego podczas wyborów samorządowych w 2018 r. Nie oznacza to jednak, że zmiany w obszarze prawa wyborczego nie są konieczne. Modyfikacje są potrzebą, ale wcześniej powinny być bardzo dokładnie przemyślane. System wyborczy jest bowiem jednym z najbardziej podanych na manipulacje instrumentów politycznych. Tymczasem uczciwa rywalizacja partyjna wymaga, aby reguły wyborcze nie były zmieniane zbyt pochopnie i często, zwłaszcza bezpośrednio przed wyborami.
\end{abstract}

Słowa kluczowe: prawo wyborcze, kodeks wyborczy, wybory samorządowe, administracja wyborcza
ABSTRACT

11 January 2018, the Sejm of the Republic of Poland enacted many amendments of the Electoral Code. These changes concerned primarily electoral administration, electoral commissions, and electoral rights. The present paper analyses practical and political consequences of the most important reforms. The author wants to prove that some of these changes, especially in the structure of the National Electoral Commission and the electoral administration as whole, may result in political and organizational crisis during the local government elections in 2018. In author's opinion, it does not mean that changes of the electoral law are utterly unnecessary. This law can be modified, but every single change must be thought over first. That is because the electoral system is the most susceptible for political manipulations. Healthy party competition requires that the election rules are not changed too frequently, especially before the election.

Keywords: electoral law, electoral code, local government elections, electoral administration

* Uniwersytet Mikołaja Kopernika w Toruniu, Wydział Politologii i Studiów Międzynarodowych. ORCID: https://orcid.org/0000-0003-4920-439X. 
11 stycznia 2018 r. Sejm RP uchwalił ustawę o zmianie niektórych ustaw w celu zwiększenia udziału obywateli w procesie wybierania, funkcjonowania i kontrolowania niektórych organów publicznych (Dz.U. z 2018 r., poz. 130). Ustawa ta w istotny sposób znowelizowała trzy ustawy o samorządzie terytorialnym oraz Kodeks wyborczy (Kwyb). Uchwalone rozwiązania już w momencie ich zgłoszenia wzbudziły dyskusję oraz liczne kontrowersje, zarówno ze strony opozycji politycznej, jak i części ekspertów. Sceptycznie na temat wielu proponowanych rozwiązań wypowiadała się również Państwowa Komisja Wyborcza (PKW). Nie bez znaczenia dla oceny przyjętych rozwiązań był fakt bardzo szybkiego tempa prac legislacyjnych nad projektem ustawy. Projekt został zgłoszony przez grupę posłów Prawa i Sprawiedliwości (PiS) 10 listopada 2017 r. Dwa tygodnie później został skierowany do I czytania na posiedzeniu Sejmu, a następnie do Komisji Nadzwyczajnej do rozpatrzenia projektów ustaw z zakresu prawa wyborczego. Po przepracowaniu przez Sejm, 15 grudnia, został przekazany do Senatu. Cykl legislacyjny ustawy zakończył się w chwili podpisania przez Prezydenta RP ustawy 15 stycznia 2018 r. i jej opublikowania dzień później w Dzienniku Ustaw. Ostatecznie ustawa weszła w życie 31 stycznia 2018 r., z tym że niektóre jej rozwiązania uzyskały dłuższe vacatio legis.

Celem niniejszego artykułu będzie analiza, jak wprowadzone powyższą ustawą zmiany w obszarze prawa wyborczego mogą wpłynąć na przebieg planowanych na jesień 2018 r. polskich wyborów samorządowych w zakresie ich organizacji, transparentności i konsekwencji dla wyborców. Zastosowaną metodą badawczą będzie metoda prawno-porównawcza.

\section{KONTEKST POLITYCZNY ZMIAN}

Analizując zmiany prawa wyborczego ze stycznia 2018 r., trzeba pamiętać o kontekście politycznym, w jakim były one zgłaszane i ostatecznie zostały uchwalone. Miał on bowiem niebagatelny wpływ na ich charakter. Bieżącym tłem był bardzo ostry konflikt polityczny pomiędzy rządzącym od $2015 \mathrm{r}$. PiS-em a tzw. totalną opozycją, reprezentowaną przez Platformę Obywatelską (PO), Nowoczesną (.N) oraz Polskie Stronnictwo Ludowe (PSL). Konflikt ten cały czas się nasilał i dotyczył praktycznie wszystkich obszarów działalności partii rządzącej. W szczególności zaś wymiaru sprawiedliwości, który z kolei od samego początku był traktowany przez PiS jako priorytetowy. Należy w tym miejscu zauważyć, że choć organy administracji wyborczej w żaden 
funkcjonalny sposób nie były elementem władzy sądowniczej III RP, to jednak w swojej zasadniczej części opierały się na elemencie sędziowskim. Zarówno PKW, jak i komisarze wyborczy w całości rekrutowali się z sędziów, podobnie jak członkowie komisji wyborczych wyższego szczebla. Ten sędziowski model administracji wyborczej miał w zamyśle twórców wzmocnić jej niezależność od pozostałych organów władzy politycznej. Z biegiem czasu stał się wręcz znakiem rozpoznawczym polskich wyborów (zob. Rymarz, 2007), co znalazło również poparcie zarówno w głosach doktryny, jak i samego wymiaru sprawiedliwości (zob. Sokala, 2014, s. 17).

Głębsze tło zmian stanowiła natomiast awaria informatycznego systemu wspomagającego Krajowe Biuro Wyborcze (KBW) podczas poprzednich wyborów samorząadowych w listopadzie 2014 r. Awaria ta uniemożliwiła większości terytorialnych komisji wyborczych sprawne zebranie od podległych im miejscowo obwodowych komisji wyborczych wyników głosowania, a w konsekwencji ustalenie wyników głosowania i wyborów radnych do rad gmin, miast, powiatów i sejmików województw. W wielu komisjach generowane z systemu informatycznego protokoły zawierały błędy, a część komisji terytorialnych nie mogła ani zweryfikować poprawności danych spływających z obwodów, ani dokonać podziału mandatów, ani nawet wydrukować protokołów z wyborów. Przedłużające się oczekiwanie na podanie oficjalnych wyników oraz nieumiejętne zarządzanie kryzysem i błędy w polityce komunikacyjnej popełnione przez PKW i KBW doprowadziły w efekcie do pogłębienia obrazu kryzysu w oczach opinii publicznej oraz dramatycznego spadku zaufania obywateli do procesu wyborczego i organów wyborczych. Rozpoczęło też falę bardzo ostrej krytyki wobec administracji wyborczej. Znalazło to natychmiastowe odzwierciedlenie w reakcjach polityków opozycyjnego wtedy PiS, którzy zarzucili rządzącej wówczas koalicji PO-PSL „zafałszowanie” wyborów. Konsekwencją tej atmosfery była gremialna dymisja PKW i kierownictwa KBW (Michalak, 2016, s. 223-225).

Kryzys przy ustalaniu wyników poprzednich wyborów samorządowych wywołał oczywistą dyskusję publiczną na temat jego przyczyn i wprowadzenia zmian, które wyeliminują takie sytuacje w przyszłości. Efektem tej dyskusji były m.in. nowelizacja Kodeksu wyborczego, przeprowadzona $\mathrm{z}$ inicjatywy ówczesnego Prezydenta Bronisława Komorowskiego (Dz.U.z 2015 r., poz. 1043), rozpoczęcie przez KBW prac nad nowym i kompleksowym systemem informatycznego wspomagania wyborów, wykonanie szeregu analiz i zgłoszenie wielu propozycji przez organizacje społeczne monitorujące procesy wyborcze, takie jak Fundacja im. Stefana Batorego czy Ruch Kontroli Wyborów (RKW), wreszcie 
przeprowadzenie unikatowego, nie tylko w skali krajowej, badania kart do głosowania $\mathrm{z}$ wyborów do sejmików województw przez interdyscyplinarny zespół badaczy z czołowych uniwersytetów w Polsce, prowadzących zaawansowane badania $z$ obszaru prawa i systemów wyborczych oraz zachowań elektoratu. W efekcie, w literaturze przedmiotu można znaleźć bardzo szczegółowe omówienie: przyczyn, przebiegu i konsekwencji samego kryzysu (zob. Flis i inni, 2015; Jarosz, 2015); konkretnych obszarów i propozycji niezbędnych zmian organizacyjnych, tak w procesie ustalania wyników głosowania i wyborów, oraz sposobu funkcjonowania struktury aparatu wyborczego (zob. Michalak, 2016); skali i konsekwencji błędów obwodowych komisji wyborczych przy ustalaniu wyników głosowania; wpływu formatu karty do głosowania na liczbę głosów nieważnych (zob. Gendźwiłł i inni, 2016; Flis i inni, 2016). Wszystkie powyższe analizy wskazywały na konieczność podjęcia szeregu konkretnych zmian w zakresie organizacji i przebiegu procesu wyborczego, dotyczących: funkcjonowania administracji wyborczej, w tym przede wszystkim relacji pomiędzy PKW a KBW; ułatwienia procedury składania protestów wyborczych; poprawy przejrzystości procesu ustalania i ogłaszania wyników wyborów; zmiany polityki informacyjno-edukacyjnej w zakresie warunków ważności głosu i procedur głosowania; ułatwień związanych z oddawaniem głosu przez wyborców; rezygnacji z karty zbroszurowanej jako standardu; przyjęcia szeregu innych drobnych z punktu widzenia organizacji procesu wyborczego, ale ważnych rozwiązań technicznych, usprawniających prace komisji wyborczych i czyniących ją bardziej transparentną (np. dokładniejszy sposób kategoryzowania głosów nieważnych czy porządkowania kart wyborczych, wprowadzanie społecznych obserwatorów wyborów itd.).

Kluczowe znaczenie dla podjęcia prac nad nowelizacją Kodeksu wyborczego, a co za tym idzie, na kierunek tych zmian miały jednak propozycje sformułowane przez związany politycznie z PiS-em Ruch Kontroli Wyborów. W dokumencie pt. Zarys koncepcji zmian systemu wyborczego (Cioska, Wolter, 2016) wskazano m.in. na konieczność: wygaszenia kadencji PKW i komisarzy wyborczych, wprowadzenia wideorejestracji w lokalu wyborczym, dostępu on-line do spisu wyborców, oddzielenia liczenia głosów od pracy obwodowej komisji wyborczej, przeprowadzającej głosowanie, natychmiastowej publikacji wyników głosownia w internecie, redukcji udziału urzędników gminnych w procesie wyborczym, likwidacji powszechności głosowania korespondencyjnego. Część postulatów RKW wynikała z przyjęcia jako podstawy, niepopartej żadnymi dowodami ani nigdy nieudowodnionej w żaden inny sposób, tezy o planowej i skoordynowanej 
ogólnokrajowej akcji fałszowania wyborów przez bliżej niezidentyfikowanych „wrogów” i „przeciwników”. Część wynikała z faktycznej nieznajomości organizacyjnych aspektów przygotowywania wyborów w Polsce (np. domaganie się redukcji udziału gmin tylko do działań technicznych w procesie wyborczym). Jednak niektóre propozycje były ciekawe i właściwie zaimplementowane mogły rzeczywiście zwiększyć zarówno sprawność, jak i przejrzystość procesu wyborczego (przykładem pomysł na digitalizację spisów wyborców czy publikowanie wyników głosowania od razu w internecie).

\section{ZAŁOŻENIA PROJEKTU}

Deklarowanym przez wnioskodawców ${ }^{1}$ celem nadrzędnym nowelizacji Kodeksu wyborczego było zwiększenie „roli społeczeństwa w procesie wybierania organów pochodzących z wyborów powszechnych, a także w kontroli tego procesu i organów odpowiadających za przygotowanie i przeprowadzenie wyborów". Zmiany te „sprowadzają się do zapewnienia należytej transparentności, przejrzystości, obywatelskiej kontroli nad procesem wyborczym oraz organami zobligowanymi do przygotowania i przeprowadzenia wyborów. Mają one [...] wyeliminować, a przynajmniej w znaczącym wymiarze ograniczyć potencjalne nadużycia oraz nieprawidłowości”. Konieczność ich wprowadzenia wynikała z kolei ze skandalu, jakim była awaria informatycznego systemu wyborczego podczas poprzednich wyborów samorządowych, spowodowane tym opóźnienia w podaniu oficjalnych wyników wyborów oraz bardzo duża liczba głosów nieważnych.

Zdaniem autorów projektu przyczyny tego kryzysu miały dwa wytłumaczenia. „Po pierwsze, jest on wynikiem niedopełnienia obowiązków przez centralny organ wyborczy, czyli ówczesną Państwową Komisję Wyborczą. Wybór wykonawcy systemu informatycznego oraz brak wyciągnięcia wniosków z wyborów samorządowych na Mazowszu w 2010 roku w zakresie formy karty do głosowania wskazują na to w sposób nie budzący wątpliwości. Fakt, że co piąty wyborca oddał głos nieważny, jest sytuacją zupełnie nieprawidłową i wskazuje co najmniej na popełnienie przez PKW błędów przy określeniu formy karty do głosowania. Błędy takie mogły mieć istotny wpływ na wynik wyborczy i w osta-

1 Zob. Uzasadnienie do poselskiego projekt ustawy z dnia 10 listopada 2017 r. o zmianie niektórych ustaw w celu zwiększenia udziału obywateli w procesie wybierania, funkcjonowania i kontrolowania niektórych organów publicznych. Druk nr 2001 Sejmu VIII kadencji. 
tecznym rezultacie najprawdopodobniej doprowadzić do jego zafałszowania, poprzez doprowadzenie do sytuacji, w których oficjalnie ogłoszony wynik nie odzwierciedla woli wyborców. Po drugie, analiza procedur wyborczych przeprowadzonych jesienią 2014 roku nie pozwala wykluczać świadomych działań na rzecz wyniku jednych komitetów wyborczych i na szkodę innych komitetów, co mogło odbywać się przy wykorzystaniu mało precyzyjnych zapisów Kodeksu wyborczego. Otwartą kwestią pozostaje pytanie o skalę takich działań, niemniej w szeregu przypadkach udokumentowano je i wskazano jako podstawę zgłaszanych do sądów protestów wyborczych. Suma takich fałszerstw faktycznie mogła również wpłynąć w istotny sposób na wynik wyborczy. Niezależnie od tego, w jakim stopniu skandal wyborczy w wyborach samorządowych w 2014 roku był wynikiem błędów w ich przygotowaniu, czy też świadomych działań, wniosek powinien być jednoznaczny. Należy zmienić prawo wyborcze w ten sposób, aby maksymalnie wyeliminować możliwość nieprawidłowości i fałszerstw w procedurach wyborczych".

Zaproponowane przez wnioskodawców zmiany w obszarze prawa wyborczego można zakwalifikować do dwóch kategorii. „Pierwsza dotyczy materialnego zabezpieczenia woli politycznej obywateli w szczególności w postaci oddanego głosu i zawiera się w zmianach odnoszących się do formy i zabezpieczenia kart do głosowania, wyposażenia technicznego lokali wyborczych, trybu obliczania głosów itp. Druga kategoria dotyczy strony podmiotowej, czyli odnosi się m.in. do organów wyborczych i innych podmiotów biorących udział w wyborczych procedurach, np. zmiany w odniesieniu do ustroju Państwowej Komisji Wyborczej i komisji niższego rzędu (terytorialnych i obwodowych komisji wyborczych), mężów zaufania, rozdzielenia funkcji komisarzy wyborczych - na wojewódzkich i powiatowych [...] oraz przydzielenia im odpowiednich uprawnień, utworzenie instytucji urzędników wyborczych itp." W konsekwencji projektodawcy zaproponowali następujące zmiany szczegółowe: zniesienie wyborów dwudniowych ${ }^{2}$ i głosowania korespondencyjnego, zmiany w wyglądzie karaty do głosowania, w tym wprowadzenie nowości w postaci symbolu graficznego komitetu wyborczego, wprowadzenie obowiązku archiwizacji kart z wyborów oraz nagrań z rejestracji czynności obwodowej komisji wyborczej, której praca w lokalu wyborczym miałaby być również transmitowana za pośrednictwem publicznie dostępnej sieci elektronicznego przekazywania danych; przyjęcie papierowej

${ }^{2} \mathrm{~W}$ praktyce wybory dwudniowe mogły być do tej pory zarządzone jedynie na potrzeby eurowyborów. 
wersji protokołu jako podstawy do wprowadzania danych do systemu informatycznego; utworzenie nowych organów wyborczych, tj. wojewódzkich i powiatowych komisarzy wyborczych z przekazaniem im kompetencji do ustalania granic okręgów wyborczych w wyborach jednostek samorządu terytorialnego, podziału gminy na obwody głosowania oraz zarządzenia druku kart w tych wyborach; wzmocnienie i rozszerzenie kompetencji mężów zaufania także o możliwość obserwacji pracy obwodowych komisji wyborczych, również przed dniem głosowania; zwiększenie kręgu podmiotów mogących ich zgłaszać o organizacje społeczne; zmiana struktury PKW przez wprowadzenie - obok 2 sędziów z TK i NSA - 7 członków rekomendowanych przez kluby poselskie; wprowadzenie instytucji skargi na wytyczne PKW do SN; podział obwodowej komisji wyborczej na dwie komisje, z których jedna przeprowadza głosowania, a druga ustala jego wyniki; wprowadzenie dwukadencyjności wójtów, burmistrzów, prezydentów miast; wprowadzenie systemu proporcjonalnego w wyborach do rad gmin; zmniejszenie i ujednolicenie we wszystkich wyborach zakresu radnych wybieranych w okręgach od 3 do 7; zmniejszenie maksymalnej liczby kandydatów na liście w wyborach do rady gminy i rady powiatu; powołanie Korpusu Urzędników Wyborczych; a także szereg drobniejszych zmian o różnym charakterze.

\section{UCHWALONE ZMIANY}

Ostatecznie nie wszystkie z proponowanych przez grupę posłów PiS zmiany znalazły się w uchwalonej 11 stycznia 2018 r. nowelizacji Kodeksu wyborczego. Ustawodawca zdecydował się zrezygnować z części propozycji najbardziej kontestowanych przez opozycję. Przede wszystkim zachowano wybory większościowe, choć ograniczono je tylko do gmin do 20 tys. mieszkańców ${ }^{3}$. Zrezygnowano też z obniżenia dolnej granicy wielkości okręgu wyborczego w wyborach gminnych do 3 mandatów, co w praktyce uniemożliwiałoby dokonanie proporcjonalnego

3 Wcześniej wybory w systemie większościowym przeprowadzono we wszystkich gminach niebędących miastami na prawach powiatu. Warto jednak pamiętać, że przed uchwaleniem Kodeksu wyborczego obowiązywało już podobne zróżnicowanie. I tak w ordynacji wyborczej do rad gmin z 1990 r. w gminach do 40 tys. mieszkańców stosowano formułę większości względnej w połączeniu z jednomandatowymi okręgami wyborczymi. Z kolei ordynacja samorządowa z $1998 \mathrm{r}$. ograniczyła stosowanie formuły większościowej tylko do gmin do 20 tys. mieszkańców dopuszczając jednocześnie tworzenie okręgów o wielkości od 1 do 5 mandatów (zob. Chmaj, Skrzydło, 2011). 
podziału mandatów w najmniejszych z nich 4 . W nowej ustawie zabrakło również instytucji wojewódzkich i powiatowych komisarzy wyborczych, zwiększono jednak liczbę dotychczasowych z 51 do 100, dając jednocześnie PKW swobodę w określeniu ich właściwości terytorialnej. Pozostawiono również w kompetencji rad gmin dotychczasowe uprawnienia związane z podziałem gminy na okręgi wyborcze i obwody głosowania, jednak tylko do końca 2018 r. Po tym terminie będą one już w gestii komisarzy wyborczych.

Omawiając zmiany, które ostatecznie zostały uchwalone, można je pogrupować w kilku kategoriach. Zostaną one przeanalizowane zgodnie $\mathrm{z}$ ich wagą i znaczeniem dla polskiego prawa wyborczego.

\subsection{Zmiany w strukturze administracji wyborczej}

Bez wątpienia najważniejszą grupą zmian były te dotyczące struktury administracji wyborczej. Art. 5 pkt 59 ustawy z dnia 11 stycznia 2018 r. wprowadził istotne modyfikacje do art. 157 Kodeksu wyborczego, regulującego skład i kadencję $\mathrm{PKW}^{5}$. Do tej pory była ona złożona $\mathrm{z} 9$ sędziów, po trzech wskazanych przez prezesów: Trybunału Konstytucyjnego, Naczelnego Sądu Administracyjnego i Sądu Najwyższego. Nowelizacja zredukowała liczbę przedstawicieli tych organów do dwóch ${ }^{6}$. Pozostałych 7 członków będzie wskazywał Sejm spośród osób mających: kwalifikacje do zajmowania stanowiska sędziego; co najmniej trzyletni staż pracy na stanowisku prokuratora, Prezesa Prokuratorii Generalnej, jej wiceprezesa lub radcy albo wykonywania zawodu adwokata, radcy prawnego lub notariusza; tytuł naukowy profesora albo stopień naukowy doktora habilitowanego nauk prawnych i pracowała w polskiej szkole wyższej lub placówce naukowej. W ten sposób wprowadzono dwie kategorie członków PKW, różnicując jednocześnie ich kadencję. Członkowie wskazani przez wymiar sprawiedliwości na 9 lat (tylko oni będą mogli pełnić funkcję przewodniczącego Komisji) oraz członkowie wskazywani przez Sejm, których kadencja będzie zbieżna z kadencją parlamentu. Mandat tych drugich będzie się kończył dokładnie 150 dni po wybraniu nowego Sejmu. Prawo do zgłaszania kandydatów „sejmowych” będą miały kluby par-

\footnotetext{
${ }^{4}$ Zmniejszono jednak górną granicę wielkości okręgów w tych wyborach z 10 do 8 mandatów (zob. art. $418 \$ 2 \mathrm{Kwyb}$ ). W pozostałych wyborach liczba mandatów obsadzanych w okręgach nie uległa zmianie.

5 Przepisy te wejdą w życie jednak dopiero po rozpoczęciu kadencji nowego Sejmu RP.

${ }^{6}$ Jeden $z$ TK i jeden $z$ NSA.
} 
lamentarne lub poselskie w proporcji do swojej wielkości, jednak w liczbie nie większej niż 3 kandydatów z jednego klubu?

Należy zauważyć, że zmiana składu PKW oznacza w tym przypadku coś więcej niż tylko zmianę jej struktury. To zmiana - zwłaszcza jeśli rozpatrywać ją łącznie z modyfikacją sposobu powoływania Szefa Krajowego Biura Wyborczego oraz komisarzy wyborczych - poddająca administrację wyborczą pod istotny wpływ czynnika politycznego: parlamentarnego w zakresie planowania i nadzoru nad organizacją oraz przebiegiem wyborów (PKW), a także rządowego w obszarze przeprowadzania wyborów (Szef KBW i komisarze wyborczy). Choć formalnie polski model administracji wyborczej nadal spełniać będzie definicyjne kryteria modelu administracji niezależnej ${ }^{8}$ (por. Sześciło, 2013, s. 95 i n.), to jednak w praktyce przypomina bardziej system kreacji wyborczego ośrodka kierowniczego, określanego w literaturze przedmiotu jako skrzyżowanie systemu politycznego (w skład tego ośrodka wchodzą przedstawiciele partii politycznych), parlamentarnego (parlament wyłania specjalne ciało wyborcze) i sądowego, co w konsekwencji prowadzi do wytworzenia modelu mieszanego (zob. Sokala, 2010, s. 39-40).

Wprowadzenie czynnika politycznego do najwyższego organu wyborczego, który oprócz zadań ściśle wyborczych jest też organem kontroli finansowania partii politycznych i rozliczania kampanii wyborczych, choć kontrowersyjne i mogące budzić uzasadnione obawy o jego bezstronność, nie jest jednak precedensem w praktyce państw demokratycznych. Nie można bowiem odmówić zasadności argumentom mówiącym o tym, że podmioty rywalizujące o władzę w wyborach powinny mieć wgląd i możliwość kontrolowania prawidłowości procesu wyborczego. Taki wgląd może tylko wzmocnić legitymizację wyborów. Ważne jest jednak, aby udział czynnika politycznego był po pierwsze jasno zdefiniowany i ograniczony do działań o charakterze monitorująco-kontrolnym, a nie władczo-zarządczym; po drugie miał charakter pluralistyczny i pozostawał w zgodzie z zasadą równości partii politycznych; po trzecie nie miał możliwości zmiany reguł

7 W przypadku, gdy w Sejmie funkcjonować będą jedynie dwa kluby, 7 kandydata wyłaniać się będzie w drodze losowania spośród dwóch dodatkowych kandydatów zgłoszonych po jednym przez każdy z klubów (zob. art. $157 \$ 4$ c znowelizowanego Kwyb).

8 Na marginesie można zauważyć, że przyjęte rozwiązanie w zasadzie zdyskredytowało obowiązującą w literaturze przedmiotu konceptualizację modelu niezależności administracji wyborczej formułowane tylko przez pryzmat jej instytucjonalno-funkcjonalnej odrębności od administracji rządowej, gdyż nie uwzględnia sytuacji, w której taka administracja - np. przez pożądany układ kadrowy - jest zależna od czynników par excellence politycznych. 
wyborczych w trakcie wyborów, a w szczególności tych, które mają bezpośrednie przełożenie na wyniki głosowania, wyborów czy wyłonienie ich zwycięzcy.

Przesunięcie polskiej administracji wyborczej z modelu administracji niezależnej w kierunku modelu administracji politycznej, to tylko jedna $\mathrm{z}$ konsekwencji nowo przyjętych rozwiązań. Drugą z nich jest - stanowiąca logiczne następstwo pierwszej - możliwa deprofesjonalizacja organów wyborczych. Mimo że 7 „sejmowych” członków PKW będzie co do zasady musiało się legitymować praktyką w zawodach prawniczych, to jednak ustawodawca dopuścił również byłych (sic!) pracowników naukowo-dydaktycznych, posiadających stopień doktora habilitowanego nauk prawnych albo tytuł naukowy profesora $\mathrm{z}$ dowolnej dziedziny. Nie przeceniając wymogu posiadania wykształcenia prawniczego, które wcale nie daje gwarancji znajomości - bardzo specjalistycznej przecież materii prawa wyborczego, należy jednak zauważyć, że z całą pewnością nie gwarantuje tego bardziej tytuł profesora nauk przyrodniczych czy matematycznych. Wprowadzone rozwiązanie należy uznać więc za kuriozalne. Jeśli ustawodawca naprawdę chciał powiązać kwestię wykształcenia akademickiego ze znajomością materii przez członków PKW, to powinien się posłużyć nie formalnym kryterium wykształcenia kandydata, ale merytoryczną oceną jego kompetencji w oparciu o rzeczywisty dorobek naukowy i doświadczenie.

Z kolei komisarzy wyborczych powoływała do tej PKW na wniosek Ministra Sprawiedliwości spośród sędziów zgłoszonych przez prezesów sądów. Procedura ta nie gwarantowała oczywiście, że każdy z nowych komisarzy był specjalistą od prawa wyborczego. W praktyce jednak na te stanowiska powoływano najczęściej osoby, które w przeszłości zasiadały - jako sędziowie - w komisjach wyborczych wyższego rzędu lub orzekały w sprawach wyborczych. Brak limitu sprawowanych kadencji dodatkowo sprzyjał profesjonalizacji tego urzędu. Nowelizacja zmieniła art. 166 Kwyb, wprowadzając jako wymóg jedynie posiadanie wykształcenia wyższego prawniczego oraz „rękojmię należytego pełnienia tej funkcji”. Ustawodawca zdecydował się również wprowadzić przesłanki uniemożliwiające pełnienie tej funkcji. Są to: przynależność do partii politycznej; prowadzenie działalności publicznej „niedającej się pogodzić z pełnioną funkcją”; bycie skazanym za przestępstwo; kandydowanie w wyborach; pełnienie funkcji pełnomocnika wyborczego lub finansowego, męża zaufania, urzędnika wyborczego czy członka komisji wyborczej. Z jednej strony - zgodnie z postulatem wnioskodawców umożliwiono dość dużej grupie obywateli dostęp do tej funkcji, z drugiej zaś stworzono możliwość do dowolnego interpretowania nieostrego przecież pojęcia „rękojmia należytego sprawowania funkcji” przez podmiot zgłaszający kandy- 
datury na komisarzy, jakim jest Minister Spraw Wewnętrznych i Administracji. Na potrzeby pierwszej rekrutacji MSWiA zarysowało własne przesłanki tej interpretacji. Tak więc, z jednej strony jest to brak różnorodnych przeciwwskazań związanych z toczącymi się (a nie zakończonymi) postępowaniami, a także zdolność do czynności prawnych. $Z$ drugiej strony kwestie merytoryczne związane ze szkoleniem i egzaminem ze znajomości prawa wyborczego przeprowadzanego na zlecenie Ministerstwa przez Narodowy Instytut Samorządu Terytorialnego (Zbieranek, 2018, s. 4).

Zmienił się również sposób wyłaniania gminnych, miejskich, powiatowych i wojewódzkich komisji wyborczych, odpowiedzialnych za ustalenie wyników wyborów do właściwych rad $^{9}$. Do tej pory kandydatów do tych komisji zgłaszali pełnomocnicy komitetów wyborczych startujących w wyborach, z zastrzeżeniem, że jej przewodniczącym (z wyjątkiem komisji gminnych) był z urzędu sędzia wskazany przez prezesa właściwego miejscowo sądu okręgowego. W przypadku nadwyżki kandydatów przeprowadzano losowanie. Znowelizowany art. $178 \mathrm{Kwyb}$ uprzywilejował komitety wyborcze utworzone przez partie polityczne lub ich koalicje, które w poprzednich wyborach wprowadziły swoich przedstawicieli do sejmiku województwa albo posłów do Sejmu. Komitetom takim zagwarantowano 6 miejsc w komisji (po 1 dla każdego takiego komitetu). Pozostałym komitetom ustawa dała jedynie 3 miejsca w każdej terytorialnej komisji wyborczej ${ }^{10}$.

Nowe brzmienie tego artykułu budzi wątpliwości natury konstytucyjnej, gdyż narusza zasadę równości komitetów wyborczych w dostępie do procesu wyborczego. Jest też niezgodne z deklarowaną, we wstępie do uzasadnienia projektu zmian, ideą zwiększenia „roli społeczeństwa w procesie wybierania organów pochodzących z wyborów powszechnych, a także w kontroli tego procesu i organów odpowiadających za przygotowanie i przeprowadzenie wyborów". W praktyce bowiem najbardziej poszkodowanymi będą lokalne i niepartyjne komitety wyborców i organizacji społecznych, które choć zgłaszają kandydatów jedynie w wyborach do rad gmin, to liczebnie stanowią największą grupę komitetów.

\footnotetext{
${ }^{9}$ W przypadku gminnych i miejskich komisji wyborczych również wyborów wójtów, burmistrzów i prezydentów miast.

10 Gdyby nie udało się skompletować danej komisji w ten sposób, to każdy z komitetów wyborczych, również tych posiadających już swoich przedstawicieli, zyskuje prawo zgłoszenia tylu kandydatów ilu brakuje do pełnego stanu. Brakujących członków wyłania się w drodze publicznego losowania.
} 
Kolejną nowością będzie konieczność powoływanie dwóch komisji wyborczych w każdym obwodzie (będzie o tym mowa w dalszej części artykułu) oraz ustanowienie Korpusu Urzędników Wyborczych. Sama instytucje urzędnika wyborczego nie jest nowa. Art. $181 \mathrm{Kwyb}$ przed nowelizacją przewidywał go jako pełnomocnika do spraw wyborów na obszarze danej jednostki samorządu terytorialnego powoływanego przez wójta (burmistrza, prezydenta), ale także starostę i marszałka województwa, w porozumieniu z KBW. Szczegółowy zakres jego zadań zależał już od treści konkretnego, fakultatywnego porozumienia pomiędzy tymi organami, zawsze jednak wiązał się z koordynacją działań organizacyjno-technicznych związanych z przygotowaniem i przeprowadzeniem wyborów i referendów na terenie danej jednostki samorządowej. W praktyce urzędnik wyborczy był kimś w rodzaju łącznika pomiędzy właściwą miejscowo delegaturą KBW, obsługującą danego komisarza wyborczego, a urzędnikami gminy, miasta, powiatu, województwa oraz członkami działających komisji wyborczych zaangażowanymi w bezpośrednie wykonywanie zadań wyborczych na obszarze danej jednostki.

Ustanowienie obowiązkowego i stałego korpusu urzędników wyborczych wraz z przypisaniem im konkretnych zadań i kompetencji ${ }^{11}$ można uznać za przejaw profesjonalizacji administracji wyborczej. Za ich powołanie (wg wytycznych PKW) i obsługę (w porozumieniu z wójtami, burmistrzami i prezydentami) odpowiadać będzie Szef KBW. Ich kadencja trwać będzie 6 lat, a kandydaci (z wykształceniem wyższym) będą się rekrutować spośród pracowników administracji rządowej, samorządowej, jednostek im podległych albo nadzorowanych. Nowo ustanowiony art. 191b Kwyb formułuje również przesłanki negatywne dla kandydatów ${ }^{12}$. Trudno jednak sobie wyobrazić jak w praktyce będzie wyglądała

11 Zgodnie z nowym art. 191e Kwyb, zadaniem urzędników wyborczych jest zapewnienie sprawnego funkcjonowania obwodowych komisji wyborczych, w szczególności zaś: przygotowanie i nadzór pod kierownictwem komisarza wyborczego nad przebiegiem wyborów w obwodowych komisjach wyborczych, tworzenie i aktualizowanie systemu szkoleń dla członków obwodowych komisji wyborczych, organizowanie i prowadzenie szkoleń dla członków obwodowych komisji wyborczych, dostarczenie kart do głosowania właściwym komisjom wyborczym, sprawowanie nadzoru nad zapewnieniem warunków pracy obwodowych komisji wyborczych, w szczególności w zakresie wymogów dotyczących urny wyborczej, wykonywanie innych czynności zleconych przez Państwową Komisję Wyborczą lub komisarza wyborczego.

12 Urzędnikiem wyborczym nie może być osoba kandydująca w wyborach w okręgu, w skład którego wchodzi gmina właściwa dla obszaru działania urzędnika wyborczego, komisarz wyborczy, pełnomocnik wyborczy, pełnomocnik finansowy, mąż zaufania lub członek komisji wyborczej, osoba ujęta w stałym rejestrze wyborców objętym zakresem działania tego urzędnika (z wyjątkiem miast na prawach powiatu), członek partii politycznej lub osoba, która prowadzi działalność publiczną 
praca tych osób, w sytuacji, w której urzędnik wyborczy nie będzie mógł wykonywać swojej funkcji w gminie, gdzie pracuje. Koordynator wyborów w gminie musi doskonale znać teren, na którym funkcjonuje. Dlatego właśnie dotychczasowa praktyka (bo nie był to obowiązek ustawowy) stosowania uchylonego art. $181 \mathrm{Kwyb}$ poszła w kierunku powoływania urzędników wyborczych spośród pracowników urzędów gminy i miast, często nawet wysokiej rangi, jak dyrektorzy wydziałów prawnych czy organizacyjnych, a nawet sekretarze gmin/miast. Znali oni bowiem doskonale teren, na jakim funkcjonowali, ze wszystkimi jego uwarunkowaniami organizacyjnymi i kadrowymi, mieli również odpowiednie zasoby i narzędzia (w postaci swojego macierzystego urzędu), które mogli szybko i efektywnie wykorzystać do realizacji stricte przecież technicznych zadań, takich np. jak rozplakatowanie obwieszczeń wyborczych, zorganizowanie pracy komisji wyborczych, wyposażenie lokali wyborczych itp.

\subsection{Zmiany w zakresie uprawnień wyborcy podczas głosowania}

Najważniejszą zmianą w tym obszarze jest przyjęcie nowej i ustawowej definicji znaku „x” (nowy art. 5 pkt $12 \mathrm{Kwyb}$ ) jako „co najmniej dwie linie, które przecinają się w obrębie kratki”. Wprowadzenie ustawowej definicji tego kluczowego dla interpretacji ważności głosu wyborców znaku należy uznać za uzasadnione. Co prawda definicja znaku „x” (dwie linie przecinające się w kratce) funkcjonuje w polskim prawie wyborczym od dawna, jednak do tej pory była to tylko interpretacja PKW zawarta w wiążących obwodowe komisje wyborcze (ale przecież już nie wyborców) wytycznych ${ }^{13} \mathrm{i}$ jako taka mogła zostać w tym samym trybie zmieniona. Sama definicja była jednak jasna, zgodna ze słownikowym i potocznym znaczeniem oraz pozwalała precyzyjnie odróżnić głos ważny od nieważnego.

niedającą się pogodzić z pełnioną funkcją, osoba skazana prawomocnym wyrokiem za przestępstwo umyślne ścigane z oskarżenia publicznego lub umyślne przestępstwo skarbowe. Urzędnik wyborczy nie może wykonywać swojej funkcji w gminie, na obszarze której ma miejsce zatrudnienia.

13 Przykładowo uchwała Państwowej Komisji Wyborczej z dnia 29 września 2014 r. w sprawie wytycznych dla obwodowych komisji wyborczych dotyczących zadań i trybu przygotowania oraz przeprowadzenia głosowania w wyborach organów jednostek samorządu terytorialnego, zarządzonych na dzień 16 listopada 2014 r. (M.P. 2014, poz. 934) pkt 65 stanowi, że „w przypadkach wątpliwych należy przyjmować, że znakiem "x» postawionym w kratce są dwie linie przecinające się, których punkt przecięcia znajduje się w obrębie kratki. Ustalenie, czy znak «X» postawiony jest w kratce, czy poza nią, należy do komisji”. 
Uznanie, wbrew ugruntowanej już w świadomości wyborców oraz członków komisji tradycji, że znak „x” to co najmniej dwie przecinające się linie w kratce, w połączeniu z rozszerzeniem kategorii dopisku niewpływającego na ważność głosu, również o dopiski w obrębie kartki ${ }^{14}$, istotnie zwiększa - wbrew intencjom projektodawców i ustawodawcy - uznaniowość obwodowych komisji wyborczych w kwestii interpretacji ważności głosu. Do tej pory dyrektywa dla komisji była jasna i precyzyjna: wszystko co nie jest znakiem „x” w kratce (czyli, dwie linie przecinające się w kratce) powoduje nieważność głosu. Natomiast wszelkie dopiski (znaki, skreślenia, komentarze, rysunki, zamazania itp.) poza obrębem kratki nie wpływają na ważność głosu i są traktowane tak, jakby ich nie było. Wykluczało to konieczność przeprowadzania dyskusji i dokonywania interpretacji, który ze znaków w kratce jest właściwym głosem wyborcy, a który jest tylko jego dopiskiem, pomyłką, poprawką itd. Chroniło to również przed dokonywaniem ewentualnych fałszerstw, polegających na zaliczaniu „dostawionych" głosów innym kandydatom lub komitetom. Co prawda taki głos stawał się głosem nieważnym, ale dzięki temu nie mógł już być zaliczony nikomu innemu. Obecne rozwiązanie otwiera drogę do sporów interpretacyjnych o to, jaki znak przypomina „x” bardziej, a jaki mniej, co będzie miało znaczenie, gdy wyborca postawi takich znaków więcej niż jeden lub dokona zamazania kratki.

Nawet jeśli założyć, co jest jednak mało prawdopodobne ${ }^{15}$, że komisje nie będą miały takich wątpliwości, to przyjęte rozwiązanie nie realizuje optymalnie intencji ustawodawcy zmierzającej do zmniejszenia liczby głosów nieważnych. Praktyka obwodowych komisji wyborczych, potwierdzona m.in. badaniami zespołu ekspertów (zob. Gendźwiłł i inni, 2016, s. 67) na reprezentatywnej próbie kart z wyborów do sejmików województw z 2014 r., pokazuje, że głosów nieważnych z powodu postawienia znaku innego niż „x” jest mało. W przywoływanym badaniu takich głosów było zaledwie 2,6\%. Większość z nich powstała w wyniku postawienia tzw. ptaszka (znaku „v”), dużo rzadziej były to przypadki „poprawianego" krzyżyka zawierającego więcej niż dwie linie, co czasami zdarza się podczas głosowania przez osoby starsze lub o niesprawności manualnej. W obecnym stanie prawnym „ptaszek” nadal będzie powodował nieważność głosu, bo jest

\footnotetext{
14 Zob. nowe brzmienie art. 41 Kwyb.

15 Jako wieloletni szkoleniowiec obwodowych komisji wyborczych nie raz spotkałem się z „podchwytliwym” pytaniem szkolonych czy „plus” (+) jest znakiem „x” czy nie? Tym bardziej jestem w stanie wyobrazić sobie wątpliwości czy klasyczny krzyżyk (x lub +) jest bardziej iksem niż np. hasz (\#), a ten z kolei czy bliższy jest iksowi niż np. piętnastoramienna gwiazdka?
} 
to po prostu linia krzywa (jedna), a nie dwie przecinające się w obrębie kratki. Jeśli zatem przyjąć za cel legislacyjny zmniejszenie liczby głosów nieważnych $\mathrm{z}$ tego powodu ${ }^{16}$, należałoby rozważyć liberalizację warunków głosu przez dopuszczenie innych znaków dających się jednoznacznie zidentyfikować jako preferencja wyborcy (przede wszystkim zaś „v”), a nie tworzenie karkołomnych i niezgodnych z powszechnym wyobrażeniem i wyborczą tradycją definicji.

Nowelizacja utrzymała jako zasadę (uchwaloną po kryzysie w wyborach samorządowych 2014 r.), że podstawową formą karty do głosowania jest pojedyncza „kartka” jednostronnie zadrukowana, która „może w razie potrzeby składać się z odpowiedniej liczby zadrukowanych jednostronnie, trwale połączonych kartek”, tworząc w ten sposób tzw. kartę zbroszurowaną. W tym drugim przypadku wskazano też na obowiązkowy układ elementów informacyjnych, jaki się musi na niej znaleźć ${ }^{17}$. Należy stwierdzić, że regulacja ta jest zgodna z postulatami ekspertów, którzy szukając przyczyn dużej liczby głosów nieważnych podczas wyborów do sejmików województw z 2014 r., dowodzą, że zastosowanie zbroszurowanej karty w wyborach samorządowych wydatnie komplikuje części wyborców możliwość prawidłowego zagłosowania i zwiększa prawdopodobieństwo oddania głosu nieważnego z powodu postawienia więcej niż jednego znaku „x” przy kandydatach z różnych list (zob. Gendźwiłł i inni, 2016, s. 63-91).

W celu przeciwdziałania zjawisku kupowania głosów wprowadzono przepis (art. 497a Kwyb) karzący za wyniesienie karty do głosowania z lokalu, jej przejęcie lub posiadanie poza lokalem. Czynność taka - bez względu na motywy osoby działającej - podlega karze grzywny, ograniczenia wolności lub pozbawienia wolności do lat 2 .

16 Takich głosów nieważnych z powodu postawienia znaku innego niż „x” wskazującego jednak jednoznacznie na któregoś z kandydatów było zaledwie 2\%. Natomiast 47,7\% wszystkich głosów nieważnych to były głosy bez wskazania żadnej preferencji (tzw. puste) a głosów z wieloma krzyżykami było 46,5\%. To właśnie te ostatnie głosy odpowiadały za drastyczny wzrost ogólnej liczby głosów nieważnych oddanych podczas wyborów samorządowych w 2014. Szerzej zob. Gendźwiłł i inni, 2016.

17 Na pierwszej „kartce karty” do głosowania umieszcza się odpowiedni tytuł („Karta do głosowania w wyborach...”) oraz czytelną informację o sposobie głosowania i warunkach ważności głosu. $\mathrm{Na}$ drugiej umieszcza się spis treści zawierający nazwy zarejestrowanych komitetów wyborczych w kolejności wylosowanych numerów, ze wskazaniem numeru kartki karty do głosowania, na której znajduje się lista kandydatów danego komitetu wyborczego, oraz symbol graficzny komitetu wyborczego. Na trzeciej i kolejnych kartkach umieszcza się poszczególne listy kandydatów każdego z komitetów wyborczych oraz - co jest kolejną nowością - symbol graficzny komitetu wyborczego (zob. art. $40 \$ 3 \mathrm{a} \mathrm{Kwyb).}$ 
Ustawa zniosła również powszechność głosowania korespondencyjnego w Polsce, funkcjonującego od 2015 r. Po protestach wielu organizacji społecznych, ustawodawca zdecydował się jednak na pozostawienie tej możliwości wyborcom niepełnosprawnym. Należy w tym miejscu zauważyć, że osób głosujących w Polsce w ten sposób jest relatywnie mało (zob. tabela 1). Nie dziwi to jednak w świetle wyników badań opinii publicznej. W przeprowadzonym przez CBOS i Biuro Rzecznika Praw Obywatelskich badaniu z kwietnia 2015 roku Polacy bardzo rzadko wskazywali na zamiar skorzystania z procedury głosowania korespondencyjnego. Zagłosować w ten sposób planowało niespełna 3\% ankietowanych, niezdecydowanych było $6 \%$, a $92 \%$ ankietowanych wykluczało skorzystanie z tej procedury (zob. Zbieranek, 2015). W rzeczywistości w wyborach z 2015 r. korespondencyjnie zagłosowało jedynie 0,03\% wyborców.

Tabela 1. Liczba wyborców głosujących korespondencyjnie w wyborach w Polsce

\begin{tabular}{|c|c|c|c|c|c|c|c|}
\hline & 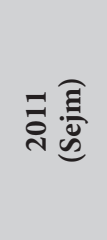 & ॠ্ & 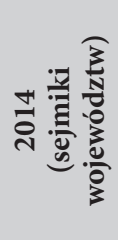 & 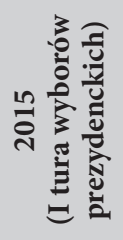 & 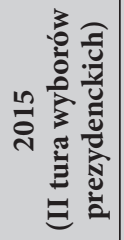 & 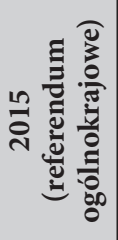 & 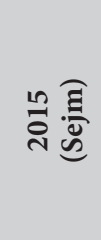 \\
\hline \multicolumn{8}{|c|}{ w kraju } \\
\hline $\begin{array}{l}\text { Liczba wysłanych } \\
\text { wyborcom pakietów } \\
\text { do głosowania } \\
\text { korespondencyjnego }\end{array}$ & 807 & 168 & 495 & 8793 & 12597 & 1432 & 9927 \\
\hline $\begin{array}{l}\text { Liczba osób głosujących } \\
\text { korespondencyjnie (kart } \\
\text { wrzuconych do urny) }\end{array}$ & 672 & 153 & 402 & 7229 & 10944 & 1183 & 8931 \\
\hline $\begin{array}{l}\text { Odsetek wszystkich } \\
\text { głosujących }\end{array}$ & $0,005 \%$ & $0,002 \%$ & $0,003 \%$ & $0,059 \%$ & $0,075 \%$ & $0,060 \%$ & $0,064 \%$ \\
\hline \multicolumn{8}{|c|}{ za granicą } \\
\hline $\begin{array}{l}\text { Liczba osób uprawnio- } \\
\text { nych do głosowania } \\
\text { korespondencyjnego }\end{array}$ & 139415 & 36375 & nd. & 196121 & 257062 & 17284 & 199451 \\
\hline $\begin{array}{l}\text { Liczba osób głosujących } \\
\text { korespondencyjnie }\end{array}$ & 16440 & 4441 & nd. & 26329 & 28360 & 2550 & 28875 \\
\hline $\begin{array}{l}\text { Odsetek wszystkich } \\
\text { głosujących }\end{array}$ & $21,27 \%$ & $23,15 \%$ & nd. & $24,47 \%$ & $33,42 \%$ & $45,86 \%$ & $24,43 \%$ \\
\hline
\end{tabular}

Źródło: opracowanie własne na podstawie danych Państwowej Komisji Wyborczej. 
Jak widać, zainteresowanie osób niepełnosprawnych głosowaniem korespondencyjnym jest również niewielkie. W latach 2011-2014 głosowało w ten sposób od 153 do 672 takich wyborców. Warto to zestawić $\mathrm{z}$ danymi Narodowego Spisu Powszechnego z 2011 r., z którego wynika, że w Polsce było w tym czasie prawie 4,7 miliona osób niepełnosprawnych, $\mathrm{z}$ tego ponad $3,1 \mathrm{mln}$ posiadało prawne potwierdzenie swojej niepełnosprawności (Skotnicki, 2014, s. 161). Z kolei jeśli chodzi o Polaków przebywających za granicą, to głosowanie przez pocztę zyskało wśród nich popularność. Odsetek głosujących w ten sposób wahał się od $21 \%$, w pierwszych wyborach dających taką możliwość, do prawie $46 \%$ spośród biorących udział za granicą w referendum w 2015 r. Faktycznymi beneficjentami głosowania korespondencyjnego w Polsce okazały się więc nie osoby niepełnosprawne ani tym bardziej Polacy w kraju, ale nasi obywatele przebywający poza Polską. Racjonalny ustawodawca powinien zatem właśnie tej grupie umożliwić dostęp do tej alternatywnej techniki głosowania.

\subsection{Zmiany dotyczące kandydowania}

Ustawodawca wprowadził zakaz równoczesnego kandydowania na wójta (burmistrza, prezydenta miast) i radnego gminy, a także powiatu i sejmiku województwa w innej gminie, niż ta, w której kandyduje się na wójta. Jednocześnie ograniczono ich kadencje do dwóch, ale tylko w odniesieniu do tej samej gminy. Zmieniając tą samą nowelizacją odpowiednie przepisy ustaw o samorządzie terytorialnym - wydłużono również kadencje organów samorządu terytorialnego do 5 lat.

Ograniczono również liczbę możliwych do zgłoszenia kandydatów wybieranych w systemie proporcjonalnym. Jako limit przyjęto wielkość okręgu wielomandatowego powiększonego o dwóch kandydatów. Dokładne analizy (zob. Flis, 2014, Marcinkiewicz, 2014) pokazują, że kandydaci umieszczeni na listach na pozycjach „niemandatowych” bardzo rzadko (poza tymi, którzy kandydują z ostatnich miejsc) zdobywają mandaty. To rodzi niepotrzebne napięcie pomiędzy kandydatami, którzy dzięki odpowiednio wysokiej pozycji na liście mają szansę na uzyskanie mandatów, a tymi, którzy tylko ją „,zapełniają", stwarzając zarówno wyborcom, jak i przede wszystkim samym sobie złudną nadzieję na sukces wyborczy. Przyjęty przez ustawodawcę limit, choć arbitralny, jest racjonalny i szkoda, że zastosowano go wyłącznie do wyborów samorządowych. 


\subsection{Zmiany w pracy obwodowych komisji wyborczych}

Kolejną ważną nowością w polskim prawie wyborczym jest podzielenie zadań obwodowej komisji wyborczej pomiędzy dwa nowe organy powoływane przez komisarzy wyborczych: obwodową komisję wyborczą ds. przeprowadzenia głosowania w obwodzie oraz obwodową komisję ds. ustalenia wyników głosowania w obwodzie. Nazwy dokładnie określają funkcje i zakres zadań tych komisji. Wielkość i skład tych komisji jest identyczny jak w przypadku terytorialnych komisji wyborczych, co powiela zarzut nierówności w traktowaniu komitetów wyborczych i uprzywilejowanie „dużych” komitetów partyjnych.

Ratio legis tego podziału polegało na powierzeniu liczenia głosów komisji, która nie jest zmęczona co najmniej 15-godzinną pracą związaną z przygotowaniem i przeprowadzeniem głosowania w obwodzie, dzięki czemu ustalenie wyników głosowania powinno trwać krócej. Dodatkowym walorem tego rozwiązania mogło być zwiększenie wzajemnej kontroli oraz fizyczne uniemożliwienie dopisywania znaków „x” na kartach niewykorzystanych i doliczanie ich określonym kandydatom i komitetom przez nieuczciwych członków komisji.

Podczas ostatniego głosowania w referendum ogólnokrajowym w Polsce w 2015 r. funkcjonowało 27788 obwodowych komisji wyborczych. W wyborach w 2018 r. będzie dwa razy więcej komisji, chociaż zapewne mniej niż $55576^{18}$. Sama skala zjawiska powoduje, że należy spodziewać się dodatkowych utrudnień organizacyjnych związanych $\mathrm{z}$ rejestracją, powołaniem, ale przede wszystkim obsługą administracyjną i funkcjonowaniem dwukrotnie większej liczby komisji tego typu. Radykalnie zwiększy się bowiem liczba członków tych komisji z ponad 250 tys. do ok. 489 tys. To potężne zwiększanie kosztów, przede wszystkim osobowych, ich funkcjonowania. Co więcej, samo rozdzielenie przeprowadzenia głosowania od liczenia głosów nie zagwarantuje większej sprawności, transparentności czy uczciwości osób liczących. Przede wszystkim proces liczenia ulegnie wydłużeniu, a nie skróceniu. Zanim obwodowa komisja wyborcza ds. ustalenia wyników głosowania w obwodzie rozpocznie swoją właściwą pracę, będzie musiała protokolarnie przyjąć materiały od swojej poprzedniczki. Ponieważ ustawodawca zamiast samej tylko urny z oddanymi głosami nakazuje jej przejęcie wszystkich dokumentów z głosowania oraz kart niewykorzystanych,

18 Zwiększył się bowiem górny zakres wielkości obwodu z 3 tys. mieszkańców do 4 tys., co przy nowym podziale gmin na obwody może wygenerować mniej obwodów ogółem, a więc i mniej komisji. 
to obydwie komisje będą musiały wspólnie te karty policzyć, zabezpieczyć spis wyborców i inne dokumenty, wreszcie dokonać protokolarnego przekazania ww. materiałów. Co gorsza, może to doprowadzić do rozmycia odpowiedzialności za ewentualne nieprawidłowości. W pewnych sytuacjach nie sposób będzie ustalić, czy błąd popełniono na etapie głosowania, liczenia kart czy rozliczania się protokolarnego komisji. Doskonałym przykładem takiej sytuacji jest bardzo częsty w praktyce wyborczej problem braku pełnego rozliczenia kart wydanych wyborcom przez komisję i kart wyjętych przez nią z urny. Dzieje się tak, gdy wyborca pobrał kartę od komisji, ale z jakiś powodów jej do urny nie wrzucił, albo sytuacja odwrotna, gdy komisja przez pomyłkę wydała wyborcy dwie karty. Wtedy liczba kart wydanych wyborcom i tych wyjętych $\mathrm{z}$ urny nie będzie się zgadzać. Komisja licząca nie będzie w stanie ustalić, dlaczego tak się mogło stać. Tylko komisja przeprowadzająca głosowanie może udzielić odpowiedzi na pytanie, czy brak rozliczenia był wynikiem jej pomyłki, działania wyborcy, czy może doszło do próby wpływania na wynik głosowania w obwodzie przez np. dorzucanie kart do urny.

Kolejną przyczyną, która zapewne wydłuży pracę komisji obwodowych, jest nałożenie na nie obowiązku sporządzenia protokołu z wyników głosowania w obwodzie przed wprowadzeniem danych do systemu informatycznego. Zgodnie z nowym brzmieniem art. 75 Kwyb taki protokół przed przekazaniem właściwej komisji wyborczej wyższego stopnia podaje się niezwłocznie do publicznej wiadomości przez wywieszenie oraz publikację na stronie internetowej PKW. Dodatkowo jego kopię musi otrzymać każdy członek komisji, mąż zaufania oraz wójt (w mieście burmistrz, prezydent).

Trzeba tutaj przypomnieć, że od momentu wprowadzenia wspomagania informatycznego w obwodach w 2004 r. jednym z najważniejszych jego celów było wyeliminowanie notorycznych błędów popełnianych przez obwodowe komisje wyborcze przy sporządzaniu papierowych protokołów głosowania. Były to błędy rachunkowe popełniane przy rozliczaniu kart i przy przepisywaniu danych na kolejnych kopiach protokołu głosowania. System wspomagania informatycznego w obwodzie wyłapywał takie błędy i nie pozwalał wydrukować i przesłać elektronicznie protokołu do czasu ich poprawienia ${ }^{19}$. Tymczasem

19 W Polsce wyniki głosowania nigdy nie były ustalane elektronicznie, tylko „ręcznie” przez członków obwodowych komisji wyborczych liczących karty do głosowania z zaznaczonymi na nich głosami. „Kalkulator wyborczy” dokonywał tylko sumowania i arytmetycznej weryfikacji ustalonych wyników, które - po autoryzacji przez członków komisji - przesyłał na serwery PKW, a następnie pozwalał wydrukować kompletne protokoły w niezbędnej liczbie egzemplarzy. Natomiast komisje 
przygotowanie protokołu z głosowania wymaga uwagi, precyzji i pewnej elementarnej wiedzy na temat przygotowania dokumentów urzędowych ${ }^{20}$. Co więcej, w protokole do głosowania zawartych jest od kilku do kilkunastu równań sprawdzających, czy członkowie komisji rzetelnie policzyli wszystkie karty do głosowania. Ma to kontrolować nie tylko prawidłowość ich pracy, ale przede wszystkim minimalizować możliwość fałszerstw polegających na preparowaniu wyników głosowania. Samo oddzielenie procesu sporządzania protokołu w obwodzie od transmisji danych nie musi oczywiście oznaczać automatycznie powrotu do „papierowych protokołów”. Art. $162 \$ 1$ pkt 1 pozwala PKW na określenie warunków wykorzystania „techniki elektronicznej”, m.in. przy ustalaniu wyników głosowania i sporządzaniu protokołu z głosowania w obwodzie. Jeśli jednak skutkiem nowelizacji miałaby być rezygnacja $z$ takiego wspomagania informatycznego, to - podobnie jak 15 lat temu - sprawdzenie poprawności arytmetycznej protokołu będzie dokonywane dopiero na poziomie komisji wyższego szczebla. W przypadku wykrytego błędu zmusza to przewodniczącego do powrotu do lokalu znajdującego się czasami nawet kilkadziesiąt kilometrów od siedziby komisji terytorialnej wyższego szczebla, zwołania w środku nocy członków swojej komisji, otwarcia spakowanych już pakietów, ustalenia przyczyny rozbieżności, prawdopodobnie konieczności ponownego przeliczenia kart, sporządzenia nowych wersji protokołów i ich kopii oraz przekazania ich adresatom, wywieszenia w lokalu nowej wersji z odpowiednią informacją, skorygowania danych w systemie informatycznym, wreszcie podróży do komisji wyższego rzędu z nadzieją, że tym razem nie popełniono żadnych błędów.

Zamiast tej swoistej informatycznej „kontrrewolucji” należało wprowadzić - co zresztą postulowało RKW i na co zwracali uwagę sami wnioskodawcy obowiązek publikowania ustalanych wyników głosowania on-line w momencie ich wprowadzania do systemu. Nie ma bowiem żadnych merytorycznych ani technicznych przeciwwskazań, aby taka ogólnopolska baza stała się oficjalnym, tyle że elektronicznym, odpowiednio oczywiście zabezpieczonym przed

wyższego rządu dokonywały już tylko formalnej weryfikacji dostarczonych jej protokołów, a więc przede wszystkim czy były to wydruki oryginalne i podpisane przez wszystkich członków obecnych przy ustaleniu wyników głosowania w obwodzie, czy komisja ustosunkowała się do ewentualnych zarzutów wniesionych przez innych członków komisji lub mężów zaufania, czy uzasadniła przyczyny ewentualnych rozbieżności między kartami wydanymi i wyjętymi z urny lub między kartami wydanymi a liczbą podpisów wyborców w spisie wyborców.

${ }^{20}$ W przypadku wyborów samorządowych będzie to od 3 do 4 osobnych protokołów dla każdej elekcji składających się z kilku do kilkunastu stron wykonanych w kilkunastu kopiach. Oznacza to konieczność sporządzenia kilkuset stron. 
modyfikacją, dokumentem z wyborów. Protokół papierowy stałby się z kolei formalnie tym, czym faktycznie był już od dawna: papierowym dokumentem archiwalnym, stanowiącym wtórnik, czy też swego rodzaju odpis właściwego dokumentu źródłowego, jakim byłby protokół elektroniczny. W konsekwencji dane elektroniczne zaraz po ich sporządzeniu, w czasie rzeczywistym, mogłyby być publikowane on-line za pośrednictwem specjalnego systemu wizualizacji wyborów, zintegrowanego z systemem wspomagania komisji wyborczych. Dla zachowania pełnej przejrzystości tego procesu wszystkie ewentualne zmiany, korekty czy błędy wychwycone już po jego sporządzeniu przez OKW lub $\mathrm{w}$ procesie weryfikacji przez TKW byłyby w tej wizualizacji zawarte z podaniem godziny, podmiotu i przyczyny modyfikacji. Zrewolucjonizowałoby to proces ogłaszania wyników wyborów i wprowadziło maksymalnie możliwą przejrzystość procesu ustalania wyników i dostępu do nich z każdego miejsca i na każdym etapie, bez żadnego obciążania komisji wyborczych i tworzenia nowych procedur czy rozwiązań informatycznych (Michalak, 2016, s. 237).

Podobnie zamiast wprowadzać kosztowny, organizacyjnie złożony i w części kontrowersyjny - ze względu na ochronę wizerunku wyborców, członków komisji czy nawet możliwość naruszenia zasady tajności głosowania - system ciągłej rejestracji i transmisji on-line pracy komisji obwodowych, rozwiązaniem równie skutecznym, a ze względu na bezpośredniość samej obserwacji nawet bardziej transparentnym, byłoby wprowadzenie możliwości publicznego liczenia głosów w obecności samych wyborców.

Z kolei zdecydowanie pozytywnie należy ocenić ustanowienie obserwatorów społecznych wyborów z ramienia stowarzyszeń i fundacji, do których „celów statutowych należy troska o demokrację, prawa obywatelskie i rozwój społeczeństwa obywatelskiego". Ich uprawnienia będą w zasadzie identyczne jak te, które posiadają mężowie zaufania. Warto odnotować, że nowelizacja poszerzyła dotychczasowe kompetencje posiadane przez mężów zaufania ${ }^{21}$ oraz je unor-

21 Art. 103b Kwyb stanowi, że mąż zaufania ma prawo: 1) być obecny podczas wszystkich czynności komisji, do której został wyznaczony, w szczególności przy przekazywaniu protokołu przez obwodową komisję wyborczą, przekazywaniu danych z protokołu, sprawdzaniu pod względem arytmetycznej poprawności i prawidłowości ustalenia wyników głosowania oraz prawidłowości ustalenia wyników głosowania, a także wprowadzania danych do sieci elektronicznego przesyłania danych; 2) być obecnym w lokalu wyborczym w czasie przygotowania do głosowania, głosowania, ustalania wyników głosowania i sporządzania protokołu; 3) wnosić do protokołu uwagi, z wymienieniem konkretnych zarzutów; 4) być obecnym przy przewożeniu i przekazywaniu protokołu do właściwej komisji wyborczej wyższego stopnia. Z kolei obserwatorzy społeczni mają uprawnienia jak mężowie zaufania z wyjątkiem punktu 3 i 4. 
mowała w Kodeksie. Do tej pory zakres tych kompetencji był określony przede wszystkim wytycznymi i wyjaśnieniami PKW, a więc aktami wewnętrznymi i de iure wiążącymi tylko same komisje wyborcze.

\section{WNIOSKI}

Zakres uchwalonej nowelizacji jest szeroki, a rozmiary artykułu nie pozwalają szczegółowo omówić ani nawet wymienić wszystkich wprowadzonych zmian. Obejmują one bowiem zarówno kwestie o istotnym znaczeniu dla politycznego wyniku wyborów (przywrócenie proporcjonalności wyborów w części gmin, ograniczenia w zasadach kandydowania wójtów, zmniejszenie wielkości okręgów wyborczych w gminach), ich demokratycznej legitymizacji - kontrowersje co do neutralności politycznej i obiektywności administracji wyborczej), uczciwości i przejrzystości (transmisja pracy komisji w internecie ${ }^{22}$, poszerzenie kompetencji mężów zaufania i ustanowienie obserwatorów społecznych, wprowadzenie obowiązku co najmniej 5-letniej archiwizacji dokumentów z wyborów, w tym przede wszystkim kart do głosowania), uprawnień wyborcy podczas głosowania (zniesienie powszechności głosowania korespondencyjnego, liberalizacja warunków ważności głosu, zmiany w wyglądzie karty do głosowania, zmniejszenie maksymalnej liczby kandydatów, karanie za wyniesienie kart z lokalu), równości komitetów wyborczych (uprzywilejowanie „dużych” komitetów partyjnych w procesie powoływania komisji wyborczych), sprawności organizacyjnej (zmiany w strukturze i podziale kompetencji w administracji wyborczej wszystkich szczebli), jak i detali regulowanych do tej pory na poziomie wytycznych PKW.

Część przyjętych zmian była już od dawna postulowana w literaturze przedmiotu i należy je ocenić pozytywnie. W szczególności można wskazać tutaj ustawowe zdefiniowanie uprawnień mężów zaufania oraz wprowadzenie instytucji społecznych obserwatorów (niestety o nieco mniejszym zakresie uprawnień); zmniejszenie liczby kandydatów na listach (choć nie w wyborach parlamentarnych, w których miałoby to największy sens); ustawowe zdefiniowanie znaku „x” (niestety błędne). Inne ze zmian, po dokładniejszym przemyśleniu

22 Art. 1 pkt 2 ustawy z dnia 15 czerwca 2018 r. o zmianie ustawy - Kodeks wyborczy oraz niektórych innych ustaw (Dz.U. z 2018 r., poz. 1349) zlikwidował obowiązek transmisji pracy obwodowych komisji wyborczych. 
i przygotowaniu ich wdrożenia, choć nie są bezwzględnie konieczne, to jednak mogłyby przyczynić się do zwiększenia przejrzystości procesu ustalania wyników głosowania i wyborów (m.in. podział zadań pomiędzy dwie komisje obwodowe, upublicznienie prac komisji, w szczególności w zakresie liczenia głosów, ustalania oraz ogłaszania wyników głosowania w obwodzie) czy profesjonalizacji działań organizacyjnych na szczeblu gminy (korpus urzędników wyborczych).

Niestety najbardziej znaczące zmiany to te, które budzą też największe wątpliwości zarówno natury politycznej, jak i organizacyjnej. Krytycznie należy ocenić zmiany w składzie PKW. Przyjęte rozwiązania w tym zakresie powodują odejście od modelu niezależnej administracji wyborczej na rzecz modelu mieszanego, z istotną przewagą czynników politycznych. Należy podkreślić, że model niezależnej administracji wyborczej jest - tak przez organizacje zajmujące się monitoringiem wyborów, jak i specjalistów od prawa wyborczego - uznawany jako najlepszy i niebudzący kontrowersji co do jego bezstronności. Z tego powodu jest zalecany - chociażby przez Komisję Wenecką Rady Europy - jako najlepszy dla państw o nieugruntowanej demokracji czy przechodzących transformację ustrojową. Argumentem jest w tym przypadku brak zaufania do administracji rządowej czy też raczej do kontrolującej ją opcji rządzącej, która, mając bezpośrednie narzędzia wpływu na proces organizowania i przygotowywania wyborów, może ulec pokusie ich nadużycia. Oczywiście w wielu państwach o ugruntowanej demokracji model rządowy funkcjonuje i nie jest kwestionowany. Jest to zatem rozwiązanie, nad którym można zastanowić się i w Polsce. Przejście z jednego do drugiego musi być jednak długotrwałym procesem, odbywającym się w warunkach pełnego zaufania wszystkich sił politycznych do administracji rządowej i z ustanowieniem takich rozwiązań instytucjonalno-proceduralnych, które gwarantowałyby transparentność całego procesu i możliwość jego kontrolowania na każdym etapie. Takim działaniem z całą pewnością nie jest oddanie PKW pod kontrolę czynnika partyjnego (nawet spluralizowanego). Nie sposób odmawiać politykom i samym kandydatom prawa do obserwowania, czy nawet kwestionowania różnych decyzji aparatu wyborczego. Jednak trudno sobie wyobrazić, aby wybrani przez Sejm politycy stanowili gwarancję bezstronności i obiektywizmu w działaniu najwyższego organu wyborczego i to w sytuacji, w której szef aparatu wykonawczego PKW również jest wskazywany przez politycznie umocowanego ministra. Pamiętać trzeba, że PKW jest również organem kontroli nad finansowaniem i rozliczaniem pieniędzy partyjnych i prowadzenia kampanii wyborczych. Trudno sobie wyobrazić, aby politycznie umocowany skład mógł ten proces rozliczania przeprowadzić bez zarzutów o stronniczość. 
Nie znaczy to, że dotychczasowe relacje na linii PKW i KBW należy uznać za prawidłowe. Przebieg kryzysu spowodowanego awarią systemu informatycznego podczas wyborów samorządowych z 2014 r. pokazał, że PKW funkcjonalnie i organizacyjnie jest za bardzo uzależniona od swojego aparatu wykonawczego. Kwestia ta wymaga reformy, na co zwracano w literaturze przedmiotu uwagę, proponując konkretne rozwiązania eliminujące ten problem bez konieczności zmiany dotychczasowego modelu funkcjonowania administracji wyborczej w Polsce. Trzeba pamiętać, że zasób kadrowy KBW, choć nieduży, to cechuje wysoki poziom specjalizacji i bezcennego doświadczenia, którego nie sposób zastąpić w ciągu kilku miesięcy przed przeprowadzeniem najtrudniejszych z organizacyjnego punktu widzenia wyborów w Polsce, a w dodatku - jak wszystko na to wskazuje - wyborów o największej temperaturze politycznego sporu.

\section{BIBLIOGRAFIA:}

Chmaj, M., Skrzydło, W. (2011). System wyborczy w Rzeczypospolitej Polskiej. Warszawa: Wolters Kluwer.

Cioska, T.H., Wolter, P. (2016). Zarys koncepcji zmian systemu wyborczego. Warszawa: Ruch Kontroli Wyborów. Pobrane z: http://ruchkontroliwyborow.pl/wp-content/ uploads/2016/05/Koncepcja-12.pdf.

Druk nr 2001 Sejmu VIII kadencji. (2017). Poselski projekt ustawy $z$ dnia 10 listopada 2017 r. o zmianie niektórych ustaw w celu zwiększenia udziału obywateli w procesie wybierania, funkcjonowania i kontrolowania niektórych organów publicznych. Pobrane z: http://www.sejm.gov.pl/Sejm8.nsf/druk.xsp?nr=2001.

Druk nr 2001 Sejmu VIII kadencji. Przebieg procesu legislacyjnego. (2017). Poselski projekt ustawy o zmianie niektórych ustaw $w$ celu zwiększenia udziału obywateli $w$ procesie wybierania, funkcjonowania i kontrolowania niektórych organów publicznych. Pobrane z: http://www.sejm.gov.pl/Sejm8.nsf/PrzebiegProc.xsp?nr=2001.

Flis, J., Frydrych, A., Gendźwiłł, A., Michalak, B., Rutkowski, J., Rychard, A., Zbieranek, J., Załuska, J. (2015). Co się stało 16 listopada? Wybory samorzadowe 2014. Warszawa: Fundacja im. Stefana Batorego.

Flis, J., Gendźwiłł, A., Haman, J., Michalak, B. (2016). Nieważne głosy, ważny problem. Postscriptum. Warszawa: Fundacja im. Stefana Batorego.

Flis, J. (2014). Złudzenia wyboru. Społeczne wyobrażenia i instytucjonalne ramy w wyborach do sejmu i senatu. Kraków: Wydawnictwo Uniwersytetu Jagiellońskiego.

Gendźwiłł, A., Cześnik, M., Flis, J., Haman, J., Materska-Sosnowska, A., Michalak, B., Pietrzyk, P., Zbieranek, J. (2016). Nieważne głosy, ważny problem. Wyniki badania kart do głosowania z wyborów do sejmików województw 2014. Warszawa: Fundacja im. Stefana Batorego. 
Jarosz, S. (2015). Informacja o wynikach kontroli wykonania budżetu państwa w 2014 r. w części 11 - Krajowe Biuro Wyborcze. Warszawa: Najwyższa Izba Kontroli.

Marcinkiewicz, K. (2014). Electoral Contexts that Assist Voter Coordination: Ballot Position Effects in Poland. Electoral Studies, 33, 322-334.

Michalak, B. (2016). Wnioski i postulaty (nie tylko) de lege ferenda w obliczu kryzysu w wyborach samorządowych 2014 r. Białostockie Studia Prawnicze, 20A, 223-241.

Rymarz, F. (red.). (2007). Iudices electionis custodes (sędziowie kustoszami wyborów). Ksiega pamiątkowa Państwowej Komisji Wyborczej. Warszawa: Państwowa Komisja Wyborcza.

Skotnicki, S. (2014). Prawa wyborcze osób niepełnosprawnych i ich gwarancje. W: E. Widawska, K. Skotnicki (red.), Społeczne i prawne aspekty funkcjonowania osób $z$ niepetnosprawnością. Częstochowa: Akademia Jana Długosza.

Sokala, A. (2010). Administracja wyborcza w obowiązującym prawie polskim. Toruń: TNOiK.

Sokala, A. (2014). Kontrowersje wokół kształtu polskiej administracji wyborczej. Studia Wyborcze, 18, 7-32.

Sześciło, D. (2013). Modele administracji wyborczej na świecie. Studia Wyborcze, 15, 93-120.

Uchwała Państwowej Komisji Wyborczej z dnia 29 września 2014 r. w sprawie wytycznych dla obwodowych komisji wyborczych dotyczących zadań i trybu przygotowania oraz przeprowadzenia głosowania w wyborach organów jednostek samorządu terytorialnego, zarządzonych na dzień 16 listopada 2014 r. (M.P. z 2014 r., poz. 934).

Ustawa z dnia 11 stycznia 2018 r. o zmianie niektórych ustaw w celu zwiększenia udziału obywateli w procesie wybierania, funkcjonowania i kontrolowania niektórych organów publicznych (Dz.U. z 2018 r., poz. 130).

Ustawa z dnia 25 czerwca 2015 r. o zmianie ustawy - Kodeks wyborczy (Dz.U.z 2015 r., poz. 1043).

Ustawa z dnia 15 czerwca 2018 r. o zmianie ustawy - Kodeks wyborczy oraz niektórych innych ustaw (Dz.U. z 2018 r., poz. 1349).

Ustawa z dnia 5 stycznia 2011 r. - Kodeks wyborczy (Dz.U. z 2001 r., poz. 112 z późn. $\mathrm{zm}$.).

Zbieranek, J. (2015). Wiedza o ułatwieniach $w$ głosowaniu przed wyborami prezydenckimi. Warszawa: CBOS.

Zbieranek, J. (2018). Komisarze wyborczy - stan prawny po nowelizacji Kodeksu wyborczego i praktyka. Warszawa: Fundacja im. Stefana Batorego. 